\title{
27. Literary Migration as Transformation
}

Paul Tenngart

Comparative Literature, Lund University

Examining how literature circulates across geographical, cultural and linguistic borders is a central task for contemporary literary studies. As other chapters in this section also demonstrate, nuanced insights into the patterns and conditions of what B. Venkat Mani calls "bibliomigrancy" - literary circulation by way of books enhance our understanding of intercultural traffic and intercultural relations in general. Such studies may focus on the material conditions for circulation - the economic reality of producing and distributing books, the establishment and maintenance of libraries or potential readers' various degrees of access to books - but in order to reach literature's significance on a more general and substantial level of intercultural communication another point of view is just as important: that of transformation. A work of literature, David Damrosch reminds us, "manifests differently abroad than it does at home", and the ways in which literature transforms when it travels tell us a great deal about intercultural manifestations as such. ${ }^{2}$

My case in point will be British and American translations of Swedish working-class fiction from the r930s. This literary

I B. Venkat Mani, "Bibliomigrancy: Book series and the making of world literature”, in Theo D'haen, David Damrosch and Djelal Kadir (eds.), The Routledge Companion to World Literature (London and New York: Routledge, 20II).

2 David Damrosch, What Is World Literature? (Princeton: Princeton University Press, 2003), 6.

How to cite this book chapter:

Tenngart, Paul. "Literary Migration as Transformation". In World Literatures: Exploring the Cosmopolitan-Vernacular Exchange, edited by Stefan Helgesson, Annika Mörte Alling, Yvonne Lindqvist, and Helena Wulff, 324-339. Stockholm: Stockholm University Press, 20I 8. DOI: https:// doi.org/Io.I6993/bat.aa. License: CC-BY. 
current has a central position in Swedish twentieth-century literature, with a distinct connection to the particularly Swedish version of the welfare state - a compromise between socialism and capitalism. The English translations of these novels amount to I 3 publications: four of these are British, five are American, and four of them are published in the USA and the UK simultaneously. In two cases, the same translation is published in the US and the UK separately by different publishers. Five of the translated texts are from the I930s, one is from the I940s, one is from the I970s, five are from the I980s, and two are published in the I990s. ${ }^{3}$ This material is, then, quite diverse: it involves two different literary markets, several historical periods, and six translators. A common

3 The I3 publications are: Harry Martinson, Cape Farewell (London: Cresset Press, I934), transl. Naomi Campbell (Kap Farväl!, Stockholm: Bonniers, I933); Harry Martinson, Cape Farewell (New York: Putnam, I934), transl. Naomi Cambell (Kap Farväl!, Stockholm: Bonniers, I933); Harry Martinson, Flowering Nettle (London: Cresset Press, I936), transl. Naomi Campbell (Nässlorna blomma, Stockholm: Bonniers, I935); Vilhelm Moberg, Memory of Youth (New York: Simon \& Schuster, 1937), transl. Edwin Björkman (Sänkt sedebetyg, Stockholm: Bonniers, 1935); Vilhelm Moberg, The Earth is Ours (New York: Simon \& Schuster, I940), transl. Edwin Björkman (Sänkt sedebetyg, Stockholm: Bonniers, I935; Sömnlös, Stockholm: Bonniers, I937; Giv oss jorden!, Stockholm: Bonniers, I939); Eyvind Johnson, I9I4 (London: Adam Books, I970), transl. Mary Sandbach (Nu var det I9I4, Stockholm: Bonniers, I934); Jan Fridegård, I, Lars Hård (Lincoln and London: University of Nebraska Press, I983), transl. Robert E. Bjork (Jag Lars Hård, Stockholm: Schildt, I935); Jan Fridegård, Jacob's Ladder \& Mercy (Lincoln and London: University of Nebraska Press, I985), transl. Robert E. Bjork (Tack för himlastegen, Stockholm: Schildt, I936; Barmbärtighet, Stockholm: Schildt, I936); Moa Martinson, Women and Appletrees (New York: Feminist Press, I985), transl. Margaret S. Lacy (Kvinnor och äppelträd, Stockholm: Bonniers I933); Moa Martinson, Women and Apple Trees (London: Women's Press, I987), transl. Margaret S. Lacy (Kvinnor och äppelträd, Stockholm: Bonniers, I933); Moa Martinson, My Mother Gets Married (New York: Feminist Press, I988), transl. Margaret S. Lacy (Mor gifter sig, Stockholm: Bonniers, I936); Ivar Lo-Johansson, Breaking Free (Lincoln and London: University of Nebraska Press, I990), transl. Rochelle Wright (Godnatt, jord, Stockholm: Bonniers, I933); Ivar Lo-Johansson, Only a Mother (Lincoln and London: University of Nebraska Press, I99I), transl. Robert E. Bjork (Bara en mor, Stockholm: Bonniers, I939). 
ground for the $\mathrm{I} 3$ publications, however, is the fact that they all execute a circulation from a peripheral literary language to a central one. ${ }^{4}$

When this domestically central Swedish literature, then, migrates to the very different political and cultural contexts of twentieth century UK and USA, its significance changes. Swedish working-class fiction is something else abroad. But how is it different? Well, that question needs multiple answers. The Swedish versions of these novels are not only reshaped into another language, but also repackaged and recontextualised. As a result of a first examination of these publications, this chapter will point out nine different kinds of transformations and a diverse set of theoretical frameworks required to analyse the changes. Faced with another material, some of these transformations may prove irrelevant, and other changes not evident in my material may instead emerge as crucial. I do think, however, that a similar set of aspects may be applied to all kinds of migrated literary material.

\section{Situation, Format and Language}

First of all, when a literary work enters a new market, it is doing so in a particular situation. The text is translated by a particular translator, edited by an editor, and published, distributed and marketed by a particular publisher. To analyse these situational conditions - and perhaps compare them to how the original text was situated in the source culture - requires theories and methods from book history and translation sociology. ${ }^{5}$ In my material, four

4 The notion of central and peripheral literary languages is primarily drawn from Johan Heilbron's analysis of translation patterns, "Towards a Sociology of Translation: Book Translations as a Cultural World-System”, European Journal of Social Theory 2 (I999): 429-44. Heilbron argues that English is a "hyper-central" language and Swedish is a "semi-peripheral" language, but his statistics are based on a particular period, the I970s and the I980s, whereas my material covers many decades. Therefore, Heilbron's more detailed relations between literary languages cannot be applied.

5 For introductions to book history and translation sociology, see Leslie Howsam, "The Study of Book History", in The Cambridge Companion 
different types of publishers are evident: small publishing houses with a narrow back list of literary fiction from abroad, large companies with a distinct commercial agenda, politically driven publishers with an ideological agenda and university presses with educational ambitions. These four types of publishers use different kinds of distribution and reach different kinds of readers. The translators can be divided into three groups: those whose principal profession is translation, those who translate texts alongside a principal occupation as writers or journalists, and academics who translate literature as a parallel activity to research and teaching.

More concrete and evident situations are created by the peritexts accompanying the translated texts in the books, including covers framing the narratives in quite a new way compared to the different Swedish editions. ${ }^{6}$ Observations like these require a book historical approach, but also narratological ideas about the role of peritexts as well as intermedial theories on the impact of covers. None of the books in my material, for example, use the same cover or cover artist as the Swedish versions. In some cases, the different versions make contrasting impressions and create contrary expectations of the novel at hand.

The most apparent situational transformation in my material occurs when Moa Martinson's novels Kvinnor och äppelträd and Mor gifter sig are published in the I980s as Women and Appletrees and My Mother Gets Married by the New York-based Feminist Press. The publisher's political agenda is highlighted by the translator Margaret S. Lacy's afterword, in which Martinson is portrayed as a feminist rather than a proletarian writer. Martinson's narratives are removed from one political situation in the Swedish I930s to quite another political situation in I980s America. The new situation makes her texts function in another way, which is further stressed by the cover paintings: American

to the History of the Book, ed. Leslie Howsam (Cambridge: Cambridge University Press, 20I 5 ) and Andrew Chesterman, "The Name and Nature of Translator Studies", Hermes 42 (2009): I3-25.

${ }^{6}$ Peritext is Gérard Genette's term for the kind of paratext that is part of the volume as such: introductions, afterwords, endnotes, covers etc. Gérard Genette, Seuils (Paris: Seuil, I987). 
artist Mary Cassatt's Baby Reaching for an Apple from I893 on Women and Appletrees and German artist Paula ModersohnBecker's Mädchenbildnis from I 905 on My Mother Gets Married. Cassatt's picture of a woman and a baby underneath an apple tree and Modersohn-Becker's portrait of a girl looking straight back at her observer signal womanhood and girlhood rather than poverty and class struggle.

In addition to these situational changes, editorial decisions also repackage the narratives into new text and book formats. In the migration process, several of the Swedish novels from the I930s have undergone substantial changes as to the arrangement of chapters, shortenings, and volumes. For example, I9I4 is a translation of the first book of Eyvind Johnson's autobiographical tetralogy Nu var det I9I4, Här har du ditt liv!, Se dig inte om! and Slutspel $i$ ungdomen. In the UK, the first part of this series is published as a single, isolated novel, giving it a sense of finality and closure it does not have in a Swedish context. Similarly, Vilhelm Moberg's trilogy Sänkt sedebetyg, Sömnlös, and Giv oss jorden! is published in two different ways. In 1937, the first part of the trilogy appears in the US as a separate novel, Memory of Youth, and in I940 the whole series is published in a single volume, The Earth is Ours. These two publishing strategies have contrasting effects: in the first case a part is isolated from the rest of the narrative, in the second case three distinctly published parts are presented as a unity.

A more important change of format in my material, however, is abbreviation. All translated texts are not abridged, but some of them are considerably shorter than their Swedish counterparts. This is especially the case in the early translations: the practice of abbreviation tends to disappear in the last decades of the twentieth century. Exclusions appear on different levels: whole chapters, sections of chapters, paragraphs, sentences, and parts of sentences. Another kind of format change, just as important as shortenings, is the inclusion of footnotes and endnotes. This kind of peritext, interweaving the literary text with asterisks or numbers, is rare in the early publications but richly used in the translations from the I980s and I990s. Abbreviations and added notes are apparent examples of how literature changes shape when it migrates. In her 
book on African editions of John Bunyan's The Pilgrim's Progress, Isabel Hofmeyr notes that migrated literary works are "excised, summarized, abridged, and bowdlerized by the new intellectual formations into which they migrate". 7 This holds true for Swedish realist narratives in the UK and the USA as well as for African versions of British Christian classics.

The most evident change in any translated material is of course the very shift from one language to another. It is crucial, however, to bear in mind that the translators' detailed work is only one kind of transformation among many in the migration process. In relation to my material, Emily Apter's notion of "untranslatability" has proven constructive to discuss the translators' struggles with certain words and concepts, especially those naming domestic and everyday phenomena, ${ }^{8}$ and Lawrence Venuti's take on the old terms "domestication" and "foreignisation" offers a good starting point to describe different translators' solutions to these problems. ${ }^{9}$ Judging from these translated texts there is, for example, one Swedish phenomenon proving more difficult to translate than any other: the habit of drinking liquor. The verb "supa" (drinking heavily, as opposed to just drinking, "dricka"), is simply translated as "drinking", and the word "brännvin" is dealt with in a variety of ways: "brandy", ${ }^{\text {ro }}$ "potato-spirit", ${ }^{\text {,1 }}$ "booze", ${ }^{\text {12 }}$ "aquavit" ${ }^{13}$ and, finally, kept as a foreign word in italics, "brännvin". ${ }^{14}$ Whereas "drinking" is a neutralisation of "supa", the words "brandy" and "booze" domesticate the kind of drink referred to,

7 Isabel Hofmeyr, The Portable Bunyan: A Transnational History of The Pilgrim's Progress (Princeton: Princeton University Press, 2004), 2f.

${ }^{8}$ Emily Apter, Against World Literature: on the Politics of Untranslatability (London: Verso, 2013).

9 Lawrence Venuti, The Translator's Invisibility: A History of Translation (New York: Routledge, I995).

10 Harry Martinson, Flowering Nettle, 7; Fridegård, I, Lars Hård, I9; Moa Martinson, Women and Apple Trees, 25.

II Johnson, I9I4, 28.

12 Lo-Johansson, Breaking Free, 29.

${ }^{13}$ Lo-Johansson, Only a Mother, 229.

${ }^{14}$ Moberg, Memory, 2I. 
while "potato-spirit", "aquavit" and "brännvin" foreignise the Swedish liquor.

\section{Distance and Integration}

Distributed on other literary markets, these texts are read in new cultural contexts framing and conditioning the understanding of the narratives. Interpreting literature, hermeneutics tells us, is very much about bridging gaps between the characters', the author's, and the reader's different historical positions. ${ }^{15}$ In translations, there is an added cultural gap, creating a cultural distance between author and reader. This recontextualisation has fundamental representational effects. Distributed and read in another context, far from its place of origin, a literary text often comes to represent more general phenomena than it represents in a context closer to home. The tendency in my material is that the translations are less distinctly connected to particular instances - a specific author, literary current, historical period and social stratum - and instead represent Swedish or Scandinavian literature, culture, society or ways of life. The hardships and injustices depicted come forth as generally Swedish, and the stylistic, thematic and narrative characteristics of these particular novels become characteristics of Swedish literature.

This kind of transformation due to cultural distance, however, not only reduces but also enlarges the novels' significance. Hermeneutic distance does not necessarily make us see less, but may enable us to acknowledge other kinds of significance, unnoticeable at a close range. Moa Martinson's novels are lifted from their firm position in Swedish literary history as proletarian narratives to a cosmopolitan context of women writers from different parts of the world. She contributes with a Swedish perspective on a vastly significant global issue. The same kind of transformation is evident in all the other novels: Moberg's, Fridegård's, Lo-Johansson's and Harry Martinson's narratives become

${ }^{15}$ Hans-Georg Gadamer, Gesammelte Werke: Band I: Hermeneutik I: Wabrheit und Methode: Grundzuge Einer Philosophischen Hermeneutik (Mohr Siebeck: Tübingen, 2010). 
internationally significant accounts of injustice, frustration, exposure and vulnerability rather than depictions of particular instances in Swedish history.

Furthermore, translations often bring an additional historical gap to the process of interpretation: that between the author and the translator. Moa Martinson's My Mother Gets Married, for example, is written in the early I930s with a 30-year distance from when it is set. With Margaret S. Lacy's translation and afterword, these two historical positions are clothed with words and perspectives from the I980s, including, for example, a late twentieth-century discourse of gender and feminism. The American translation also includes a foreword by the author written for a new edition of the novel in 1956. Interpreting the novel involves, then, a navigation through five layers of different historical positions: the reader's own position, the translator's I980s, the foreword's I950s, the I930s of Martinson's writing, and the setting's first decade of the twentieth century. These historical gaps interfere with the cultural distance between reader and author, and vice versa: the cultural gap between translator/ reader and writer/characters complicates the process of abridging the historical distance, threatening to blur the impressions of historical distinctness.

The ways in which cultural phenomena in the texts are understood differently by target culture readers compared to source culture readers is a hermeneutic question with a distinct anthropological significance. In Gabriele Schwab's words, translated literary texts function as "imaginary ethnographies", ${ }^{16}$ interpreted with the help of other sets of references than the original text. For a Swedish reader, for example, these novels have a distinct position in twentieth-century literary history and are understood as a special kind of literature, arbetarlitteratur, written from a particular social and historical point of view. For British and American readers, however, these narratives first and foremost come forth

${ }^{16}$ Gabriele Schwab, Imaginary Ethnographies: Literature, Culture, \& Subjectivity (New York: Columbia University Press, 201 2). 
as Swedish, and the depiction of customs and conditions is given a cultural rather than a social and historical significance.

At the same time, the translations also become integral parts of the target culture. With the help of polysystem theory, the Swedish novels can be related to different existing literary cultures, for example the tradition of social realism in the UK and the USA. ${ }^{17}$ There are many ways in which a translated text can be connected to a particular domestic sphere in the target culture. In my material, cover texts, afterwords and footnotes include quite a few comparisons to British and American literary and social events and phenomena. Other integrating connections are made in reviews and introductions. Furthermore, readers themselves have most certainly been prone to understand these narratives from their own cultural points of view via domestic counterparts. Here, it is important to bear in mind that the USA differs distinctly from the UK in that it has a Scandinavian-American minority culture for which these novels have a special audience. This is illustrated by the fact that three out of four American translators have Scandinavian roots: Edwin Björkman (Moberg), Robert E. Bjork (Fridegård and Lo-Johansson) and Margaret S. Lacy (Moa Martinson). The different ways in which these novels become integral parts of British and American majority or minority cultures of course affect the way in which the cultural phenomena depicted are perceived and understood.

\section{Formal, Generic and Thematic Changes}

Since there is never a one-to-one relation between different languages, literary translations often include changes in the use of literary devices. This kind of formal transformation is also found in British and Americans versions of Swedish working-class fiction. Due to substantial differences between Swedish and English, the translators have occasionally been forced to make significant changes in the novels' narrative techniques. This happens,

${ }^{17}$ See Itamar Even-Zohar, "Polysystem Studies", Poetics Today I I, no. I, (I990). 
for example, when dramatic shifts of tense are skipped or a dialect-based free indirect speech has proven too difficult to keep. The tendency is that the translators make the narrative techniques less complex and more smoothly accessible, but these changes not only neutralise the narrative and the stylistic peculiarities of the Swedish authors, but also, and more significantly, create new kinds of narratives from the stories at hand. In Eyvind Johnson's I 9 I4, for example, the translator Mary Sandbach has added inverted commas to separate the characters' thoughts from the words of the anonymous narrator. Thereby, Johnson's fuzzy boundaries between narrator and characters are made distinct, and the narrative becomes more of an outside gaze into a foreign world than an account from within. A substantial analysis of this kind of observation requires a narratological framework. ${ }^{\mathrm{I}}$

A couple of texts in my material undergo slight generic changes when translated. For example, a peritext can stress the autobiographical element of a novel so much that the text appears to be more of a direct testimony of a foreign life than an aesthetic account of a general experience. The use of explaining footnotes and endnotes enhances this impression, rendering the novels a distinct anthropological value and reshaping them from fiction to ethnographic sources. This kind of transformation occurs much more in the later than in the early translations, with a distinct shift around I980. The most evident reason for this change is the fact that the later translations are predominantly published by university presses, with a focus on educational distributions and readerships. Generic changes are best studied through the lens of

is The modern fundamentals of this framework are found in Gérard Genette's Figures I-III from I967-1970 (Figures I, Paris: Seuil, 2007; Figures II, Paris: Seuil, 2007; Figures III, Paris: Seuil, I999), of which Narrative Discourse: An Essay in Method (Ithaca: Cornell University Press, 1983) is a selection, and in Dorrit Cohn, Transparent Minds: Narrative Modes for Presenting Consciousness in Fiction (Princeton: Princeton University Press, I978). A more recent approach to the relation between narrator and character is found in Alan Palmer, Fictional Minds (Lincoln: University of Nebraska Press, 2004). 
genre studies and its development within and outside the discipline of literary studies. ${ }^{19}$

The cultural gap also has the tendency to affect the very themes of the novels. The new cultural context frames the understanding of the text in a way that makes it appear to be about something slightly different. To analyse this kind of thematic transformation, we need a hermeneutic perspective based on the texts' recontextualisations. Being isolated on the autumnal potato fields in northern Sweden, for example, the young protagonist of Johnson's I9I4 is ignorant of the war going on in many parts of Europe. For a Swedish reader, this ignorance enhances the theme of alienation. The protagonist is stuck. He is trapped in the outskirts of the world, too remote from everyone and everything else to be able to change his situation. In Britain, where young working-class men were forced unto the continent to be killed en masse at the front, this non-participation in the world events may very well be seen as a lucky stroke of God's grace. The protagonist is spared, and when the war ends he will get on with his life. In Moa Martinson's Women and Appletrees and My Mother Gets Married, the cultural and historical gaps work together in transforming the narratives from being working-class novels written from a female point of view to being feminist or proto-feminist narratives from a working-class perspective. This substantial shift is first and foremost enforced by the translator's afterword and the publishing situation, and it has a fundamental impact on the understanding of the narratives, putting some of the novels' motifs in focus at the expense of others.

\section{World Perspectives}

Finally, in recent literary scholarship, world literary theory has revitalised the concept of world-making in order to discuss what kind of relation to the world literary texts from different traditions encompass and evoke. ${ }^{20}$ Culturally recontextualised texts

\footnotetext{
19 For an overview, see John Frow, "'Reproducibles, Rubrics, and Everything You Need': Genre Theory Today”, PMLA I 22, no. 5 (2007).

${ }^{20}$ Pheng Cheah, "What is a World? On World Literature as World-making Activity", Doedalus I37, no. 3 (2008): 26-38.
} 
are especially relevant cases to study from this perspective, since they are able to offer significantly different alternative outlooks upon the world we all share. At the end of Moberg's The Earth Is Ours, for example, the protagonist Knut Toring experiences a strong feeling of a two-fold belonging: he belongs in the small Swedish village of Lidalycke and "on this earth". ${ }^{21}$ This existential insight is prompted by the conflict between Adolf Hitler and Neville Chamberlain at the negotiation in Munich in 1938 and the threat of a new European war. The novel's concept of "this earth" is thus primarily European. From a Swedish perspective, Knut's insight reflects a similar position for the reader: every Swedish city, town or village is dangerously close to the escalating conflict down south. But whereas a Swedish reading perspective is placed within Knut's world, an American perspective exists outside its borders. In one sense, then, the American reader is an outsider looking into European affairs from a distance, but by reading about the world through the eyes of the protagonist he or she is simultaneously invited to share Knut's perspective. Unlike the contemporary Swedish reader, the translation reader is thus offered a negotiation of perspectives. ${ }^{22}$

An analysis of a text's world can be done in a number of ways. A method that has proven very fruitful in my material is a simple mapping of geographical and cultural references in order to grasp the scope of the novels' and their characters' worlds. ${ }^{23}$ In this respect, the narratives show huge differences. Eyvind Johnson's I9I4, for example, contains mostly local and very few international references, whereas Harry Martinson's Flowering Nettle is crammed with associations to and thoughts of places and phenomena from all over the world. Physically, the protagonists in these novels are equally bound to a limited place, but in their

${ }^{21}$ Moberg, The Earth, $62 \mathrm{I}$.

${ }^{22}$ For a discussion of the dynamics between the regional, the national and the cosmopolitan in all these novels, see Paul Tenngart, "Local Labour, Cosmopolitan Toil: Geo-Cultural Dynamics in Swedish Working-Class Fiction", Journal of World Literature, no. 6, 2016.

${ }^{23}$ For preliminary results of this mapping, see Paul Tenngart, "The Bamboos of Blekinge: The Writing of Cultures in Swedish Proletarian Fiction", Journal of Literature and Art Studies 5, no. 7, 201 5. 
minds their worlds are very different in geographical and cultural scope. Johnson's and Martinson's narratives thus represent two very different ways of experiencing the world, reminding us that outlooks upon the world are not merely conditioned by broadly drawn national, cultural and social belongings. Taken together, Swedish working-class narratives from the I930s will give the reader a very diversified account of the world, despite the fact that they are all Swedish and written from a common historical and social perspective. Read separately and at a cultural distance, however, any of these novels may be understood as encompassing a general Swedish I930s working-class perspective on the world.

\section{Conclusion}

The kinds of transformation due to literary migration observed here are very different from one another. They are caused by different conditions, they have different effects, and they require different theoretical frameworks in order to be substantially analysed. Examining them one by one from separate theoretical perspectives is clearly possible, but it will not enable us to reach a general impression of how a text or a set of texts manifests in new languages and contexts. All these kinds of transformation are active at the same time, impacting each other - sometimes confirming each other, sometimes enhancing each other, and at other times ruling each other out or giving contradictory impressions. In other words, their interrelations are very complex, and we need to address them all together.

One fundamental distinction is important to make. Five of these transformations exist on a more basic level than the others. Changes in situation, format, language, hermeneutic distance and cultural context are all necessary recodings that constitute the migration process. The other four - formal, generic and thematic changes, and changes in world perspectives - are rather secondary effects prompted by the inevitable recodings. In addressing all the transformations together, this distinction will help us see their interconnections and structure our further examinations. 


\section{Bibliography}

Apter, Emily. Against World Literature: On the Politics of Untranslatability. London: Verso, 2013.

Cheah, Pheng. "What is a World? On World Literature as Worldmaking Activity". Doedalus I37, no. 3 (2008): 26-38.

Chesterman, Andrew. "The Name and Nature of Translator Studies". Hermes, 42 (2009): I3-25.

Cohn, Dorrit. Transparent Minds: Narrative Modes for Presenting Consciousness in Fiction. Princeton: Princeton University Press, I978.

Damrosch, David. What Is World Literature? Princeton: Princeton University Press, 2003.

Even-Zohar, Itamar. Polysystem Studies. Poetics Today II, no. I (I990).

Fridegård, Jan. Jag Lars Hård. Stockholm: Schildt, I935.

—. Tack för himlastegen. Stockholm: Schildt, 1936.

—. Barmbärtighet. Stockholm: Schildt, 1936.

-. I, Lars Hård. Translated by Robert E. Bjork. Lincoln: University of Nebraska Press, I983.

—. Jacob's Ladder \& Mercy. Translated by Robert E. Bjork. Lincoln: University of Nebraska Press, I985.

Frow, John. “'Reproducibles, Rubrics, and Everything You Need': Genre Theory Today". PMLA I22, no. 5 (2007).

Hans-Georg Gadamer. Gesammelte Werke: Band I: Hermeneutik I: Wabrheit und Methode: Grundzuge Einer Philosophischen Hermeneutik. Mohr Siebeck: Tübingen, 20 Iо.

Genette, Gérard. Narrative Discourse: An Essay in Method. Ithaca: Cornell University Press, I983.

-. Seuils. Paris: Seuil, 1987.

—. Figures III. Paris: Seuil, I999. 
—. Figures I. Paris: Seuil, 2007.

- Figures II. Paris: Seuil, 2007.

Heilbron, Johan. "Towards a Sociology of Translation: Book Translations as a Cultural World-System". European Journal of Social Theory, 2 (I999): 429-44.

Hofmeyr, Isabel. The Portable Bunyan: A Transnational History of The Pilgrim's Progress. Princeton: Princeton University Press, 2004 .

Howsam, Leslie. "The study of book history". In The Cambridge Companion to the History of the Book, edited by Leslie Howsam, I-I3. Cambridge: Cambridge University Press, 2015.

Johnson, Eyvind. Nu var det I9I4. Stockholm: Bonniers, I934.

—. I9I4. Translated by Mary Sandbach. London: Adam Books, I970.

Lo-Johansson, Ivar. Godnatt, jord. Stockholm: Bonniers, I933.

—. Bara en mor. Stockholm: Bonniers, I939.

. Breaking Free. Translated by Rochelle Wright. Lincoln and London: University of Nebraska Press, I990.

- Only a Mother. Translated by Robert E. Bjork. Lincoln: University of Nebraska Press, I99I.

Mani, B. Venkat. "Bibliomigrancy: Book Series and the Making of World Literature". In The Routledge Companion to World Literature, edited by Theo D'haen, David Damrosch and Djelal Kadir, 283-96. New York: Routledge, 20I I.

Martinson, Harry. Kap Farväl!. Stockholm: Bonniers, I933.

- Cape Farewell. Translated by Naomi Walford. London: Cresset Press, I934.

Cape Farewell. Translated by Naomi Walford. New York: Putnam, I934.

. Nässlorna blomma. Stockholm: Bonniers, I935. 
- Flowering Nettle. Translated by Naomi Walford. London: Cresset Press, I936.

Martinson, Moa. Kvinnor och äppelträd. Stockholm: Bonniers I933.

—. Mor gifter sig. Stockholm: Bonniers 1936.

- Women and Appletrees. Translated by Margaret S. Lacy. New York: Feminist Press, 1985.

. Women and Apple Trees. Translated by Margaret S. Lacy. London: Women's Press, I987.

- My Mother Gets Married. Translated by Margaret S. Lacy. New York: Feminist Press, I988.

Moberg, Vilhelm. Sänkt sedebetyg. Stockholm: Bonniers, I935.

—. Sömnlös. Stockholm: Bonniers, I937.

—. Giv oss jorden! Stockholm: Bonniers, I939.

- Memory of Youth. Translated by Edwin Björkman. New York: Simon \& Schuster, I937.

- The Earth is Ours. Translated by Edwin Björkman. New York: Simon \& Schuster, I940.

Palmer, Alan. Fictional Minds. Lincoln: University of Nebraska Press, 2004 .

Schwab, Gabriele. Imaginary Ethnographies: Literature, Culture, \& Subjectivity. New York: Columbia University Press, $20 \mathrm{I} 2$.

Tenngart, Paul. "The Bamboos of Blekinge: the Writing of Cultures in Swedish Proletarian Fiction". Journal of Literature and Art Studies 5, no. 7 (201 5): 495-504.

—. "Local Labour, Cosmopolitan Toil: Geo-Cultural Dynamics in Swedish Working-Class Fiction". Journal of World Literature I, no. 4 (2016): 484-502.

Venuti, Lawrence. The Translator's Invisibility: A History of Translation. New York: Routledge, I995. 